\title{
Interfaces
}

INTERFACES Image Texte Language

$41 \mid 2019$

Images / Memories

\section{Recycled Images as Layers of Meaning in Picture Books}

Isabelle Gras

\section{Q OpenEdition \\ 1 Journals}

\section{Electronic version}

URL: http://journals.openedition.org/interfaces/646

DOI: $10.4000 /$ interfaces.646

ISSN: 2647-6754

\section{Publisher:}

Université de Bourgogne, Université de Paris, College of the Holy Cross

\section{Printed version}

Date of publication: 21 June 2019

Number of pages: $45-63$

ISSN: 1164-6225

\section{Electronic reference}

Isabelle Gras, "Recycled Images as Layers of Meaning in Picture Books", Interfaces [Online], 41 | 2019,

Online since 21 June 2019, connection on 04 January 2021. URL: http://journals.openedition.org/ interfaces/646; DOI: https://doi.org/10.4000/interfaces.646

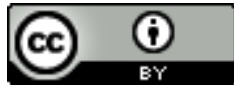

Les contenus de la revue Interfaces sont mis à disposition selon les termes de la Licence Creative Commons Attribution 4.0 International. 


\title{
RECYCLED IMAGES AS LAYERS OF MEANING IN PICTURE BOOKS
}

\author{
Isabelle Gras \\ Université Bordeaux Montaigne
}

\section{Introduction}

Picture books — whose unique nature rests on the relationship between text and image — provide many examples of the recycling of themes or motifs, through multiple versions of tales or myths, for instance. Though the medium is still mostly considered as typical of children's literature, many contemporary authors and illustrators tend to address both the children and the adults who read for them. In the 1950s, graphic designers started to create picture books, using words as pictorial elements and revealing "the potential of the page" as a visual stage (Salisbury and Styles 29). Techniques or images borrowed from advertising, photography, cartoon or cinema entered the flexible space of the picture book page or double page. Collage, adopted by many artists - such as Dave McKean or Shaun Tan, whose images will be examined in this paper - has made it possible to recycle textual and pictorial elements from a previous work in a new image.

At the heart of the concept of picture book lies the multiplication of images which makes "the art of visual storytelling" available to a large audience (Salisbury and Styles). Bringing an artist's image to a large audience questions the status of the work of art. Walter Benjamin was among the first to point out that massive reproduction deeply modified the impact of a work of art upon the public. Linked to the notion of authenticity, the concept of the aura highlights the shift in the function of the work of art as multiplication enables everyone to get access to it. This calls into question the function of the reproduced or recycled image in picture books.

This paper contends that picture books provide a new narrative context in which recycled images or elements are integrated in the composition of a different picture and function as layers of additional meaning. The first part examines the transformation of meaning operated by the reproduction and recycling of images, and it identifies the type of meaning involved, drawing on Gunther Kress and Theo van Leeuwen's systemic functional model of visual meaning. This will lead to a re-interpretation of Benjamin's concept of "aura" in that specific context. The two following parts will examine the 
processes operating in the recycling of images, according to the type of meaning developed, to determine the function of recycled images in The Day I Swapped My Dad for Two Goldfish and The Wolves in the Walls, written by Neil Gaiman and illustrated by Dave McKean and The Lost Thing by Shaun Tan.

\section{1. Transformation of meaning through recycling}

Originally used for industrial processes, recycling came to describe the action of converting waste material into something reusable in 1960, and as the concept became a social concern, its meaning diversified to include the action of adapting something to a new use. In the field of images, adaptation thus involves changes in size, style or colors, adding, removing or extracting represented elements to create a new image which refers to the original work of art more or less directly, in a process reminiscent of intertextuality in literature. Intertextuality posits a text as a translinguistic system referring to "all other texts" converging with history and reality (Kristeva 85). In its relationship to other texts, a text is not exclusively considered as the product of a single author, and the notions of authorship and authenticity are no longer relevant. In order to account for the specific features of the visual mode, scholars have adapted and developed the concept of intertextuality into intericonicity (Arrivé; Beylot; Chéroux; Hariman and Lucaites; Latour).

In her introduction to intericonic meaning, Mathilde Arrivé considers Erwin Panofsky's approach to iconology as a potential basis for an intericonic interpretation (Arrivé). Panofsky's analysis of meaning in works of art rests on the distinction between subject matter or meaning, and form. His principle of disjunction allows him to explain how Medieval art appropriated either classical motifs without their themes, or classical themes without their motifs: he notes the "mediaevalization of classical motifs by the infusion of Christian content" and the "mediaevalization of classical subject matter by presentation in contemporary form" (Panofsky, "Renaissance and Renascences in Western Art" 220). The reintegration of classical themes and forms in Renaissance art rested on a reconstruction process which was achieved by two main methods that could be used separately or in combination. "Reinterpretation" describes the way in which an image is invested with a new meaning through contrast, re-composition or assimilation. "Pseudomorphosis" accounts for the transformation of one motif into another, expressed by a change in the attributes of the represented character, through time:

When a classical character had emerged from the Middle Ages in utterly non-classical disguise [...], and had been restored to its original appearance by the Renaissance, the final result often showed traces of this process. Some of mediaeval garments or attributes would cling to the remodelled form, and thereby carry over a mediaeval element into the content of the new image. (Panofsky, Studies in Iconology 70) 
This transformation subsequently modifies the meaning of the image. The notion of reinterpretation, with the emergence of a new meaning in the same image through composition processes, seems to be adaptable to the recycling processes in picture book images. As contemporary picture book artists appropriate characters of traditional tales, like the wolf for example, they transform the representation codes to fit the personality they intend to depict, in a process reminiscent of Panofsky's "pseudomorphosis". So, Panofsky's categories may prove useful to understand the recycling processes in picture book images. The transformation of a material involved in the concept of recycling is reminiscent of Gérard Genette's notion of palimpsest, which he describes as “toutes les œuvres dérivées d'une œuvre antérieure, par transformation ou par imitation" (Genette).

\subsection{Layers of meaning in the recycled image}

The processes of imitation and transformation in literature parallel Panofsky's "emulation and reconstruction" in arts, and thus Genette's conception of the palimpsest could be extended from literary works to artistic works as well. Moreover, the literal meaning of palimpsest - altering a medium to create a new work - makes it very similar to a recycling process which can be used for text and art alike. Indeed, collages are made of successive layers which add visual meaning to the background or the elements they are pasted on.

In the $20^{\text {th }}$ century, scholars showed that images function as a semiotic mode conveying visual meaning (Edeline, Klinkenberg, and Minguet; Kress and van Leeuwen). Kress and van Leuuwen developed a systemic functional model of visual meaning based on M.A.K. Halliday's three metafunctions of language, arguing that they can be found in any semiotic mode. The ideational metafunction is concerned with representing aspects of the world, as it is experienced by humans. The interpersonal metafunction accounts for the representation of the relations between the author or illustrator, the reader or viewer, and the object represented. Finally, the textual metafunction encompasses the compositional organization of messages whether visual or written. Drawing on Kress and van Leeuwen's systemic functional approach to images, Clare Painter, James Martin and Len Unsworth developed new systems to describe the pictorial features in picture books, according to the type of meaning conveyed.

In the visual mode, the ideational meaning is conveyed through the representation of objects, such as characters or settings, their relations to other objects, and processes such as actions and reactions. Actions, like speaking or thinking, are typically represented in comics as speech or thought bubbles, processes which can also be found in picture books, as will be seen in the second part of this paper. 
The interpersonal meaning is developed through choices of style of representation, number of elements, size, colors or focalization. Through processes of zooming in and out, focalization guides the reader's gaze in the image, while color and size single out elements which require interpretation. Finally, the textual meaning is revealed by the compositional organization of a page or a double page and involves choices in the relative positions of focus groups - which, in this paper means groups of represented elements - and choices in layout and framing. The second part of this paper will show how the frames of images can become recycling spaces.

When a picture book image recycles characters or settings of a previous work, it provides an ideational meaning that can be directly perceived and another type of meaning that can be inferred through familiarity with the original work. Children will be able to perceive what Roland Barthes calls "the literal message" of the image, or what is denoted by it (Barthes 42), but they may not possess the cultural experience to understand the connoted meaning present in the recycled element, which could be supplied by an adult reader. This type of meaning involving the artist, the child viewer, the represented element and the adult reader, is interpersonal. Color, depiction style and texture, which all contribute to creating an emotional effect on the viewer, can also be considered to convey interpersonal meaning. The different layers of meaning of a recycled image thus point to specific functions.

\subsection{The functions of the recycled image}

Benjamin mentions the new functions of the work of art as a consequence of its massive reproduction, causing the decay of what he calls its "aura," which rests on the "unique phenomenon of a distance, however near it may be" (Benjamin III). He considers this distance to be a feature of art's origins in ritual: "the unique value of the 'authentic' work of art has its basis in ritual, the location of its original use value" (Benjamin IV). Massive reproduction cancels the unique existence of the cult image and the distance that surrounds it. While regretting the passing of the aura, Benjamin considers that "mechanical reproduction emancipates the work of art from its parasitical dependence on ritual" (Benjamin IV). His description of the process of reproduction highlights the detachment of the reproduced object from ritual and the reactivation of the object through its copies. Similarly, the recycling of images borrows characters or settings from original works and repurposes them in a different image. Benjamin notes that the reproduced image has functions that the original cannot fulfill such as the possibility "to meet the beholder or listener in his own particular situation" (Benjamin II). By reactivating the original, the copies allow a large number of people to see it, if not to experience it. This also holds true for picture books, in which reproduction and recycling allow viewers to discover works of art. The recycled image 
thus fulfills a cultural function, which in picture books is tied to a pedagogical dimension as the cultural references may need to be explained by an adult to a child reader or viewer. How is this cultural and pedagogical function of the recycled image expressed in contemporary picture books?

The picture books selected to answer this question enrich the pedagogical dimension mentioned above since their authors and illustrators do not exclusively target children. Neil Gaiman and Dave McKean started to co-author picture books about ten years after creating graphic novels together. While Gaiman explains that he tends to write books for adults which children can enjoy too, ${ }^{1}$ McKean uses the same mixed technique in his illustrations for children as in his graphic novels. The Day I Swapped My Dad for Two Goldfish and The Wolves in the Walls, that Gaiman and McKean co-authored in 1997 and 2003 respectively, recycle themes and motifs from children's and adult literature. Shaun Tan's picture books elude any attempt at categorization regarding an audience. He explains that he doesn't create a book with a specific public in mind (Tan, "Picture Books: Who Are They For?") and considers that the limitation of picture books to children is a cultural convention. The Lost Thing, published in 2000 , is a tale which raises contemporary social issues.

\section{Gaiman and McKean: recycling of themes and motifs through pseudomorphosis}

\section{1. A playful series of intericonic references: The Day I Swapped My Dad for Two Goldfish}

In The Day I Swapped My Dad for Two Goldfish, Gaiman imagines the circumstances and the consequences of a swap suggested to him by his own son when he was angry with him. From a literary point of view, the absurd exchange of the father for goldfish evokes the tradition of nonsense, from Edward Lear and Lewis Caroll to Roald Dahl. From a psychological point of view, it hints at the way children discover the world and experience all kinds of possibilities as they learn social codes. The social experience of the boy and his younger sister going from place to place to recover their swapped father is paralleled by the pictorial experiences which McKean reveals to his readers. Rough color strokes, ink blotches, uneven layers of paint revealing underlying newspaper collages, colorless silhouettes on a background of painted collages, all display the making of the image. Recycling processes work on several levels in this picture book. While Gaiman's text borrows features from different types of

In an interview with Celia Richard, he explains: "trying to write a book that I know the children will read [...] I want to write an adult book that kids would enjoy too, rather than writing kids' books that adults wouldn't" (Gaiman and Richard). 
narratives, such as the tale, the quest and the realistic narrative, McKean's hybrid images borrow composition and representation processes from other arts or genres such as comics, scrapbooks, and cinema. Besides the recycling of visual processes, the book illustrations reveal layers of recycled materials through the use of collages, and recycled motifs from various works of art.

As Virginie Douglas remarks, the front cover of the 1997 edition of The Day I Swapped My Dad for Two Goldfish is an obvious reference to René Magritte. While she sees a reference to L'Homme au chapeau melon (Douglas 134), McKean's character with his fishbowl head, is directly reminiscent of Magritte's Le Fils de l'homme, whose head is hidden behind a big, round apple, and who is wearing a similar suit and bowler hat. McKean elaborates on Magritte's idea, by replacing the man's head with a fishbowl with two goldfish in place of his eyes. So, the first cover of the picture book immediately signaled the intericonic dimension of the images through a pseudomorphosis process. In 2004, McKean changed the cover, replacing the representation of the father with that of the boy and his sister but keeping from the first cover the representation of the eyes as goldfish. So, the allusion becomes intraiconic, as it refers to the first cover of the picture book and to the hybrid father whose head is evoked by a fishbowl.

Another example of pseudomorphosis appears when the hero tries to find something that his friend Nathan would accept to swap for his two goldfish. While Gaiman's text evokes the boy's thoughts in the way of a stream of consciousness, McKean elaborates on the abstract textual meaning by depicting the hero seated, his body bent forward, his elbow resting on his knee and his chin on his hand, in an attitude very similar to that of Auguste Rodin's Le Penseur.

Although adult readers are likely to recognize the intericonic reference, this may not be the case for young readers. However, the position of the boy's body focuses the reader's gaze on his head. The vectors formed by the line of his back and his bent forearm point to his head as the center of the image. The large oval which encompasses the boy's hair through a texturing effect of engraving is depicted as an extension of his head. So, the complicated pictorial content of the oval appears as his thoughts. The group of concentric and superimposed circles linking the oval to the boy's head makes it look like a thought bubble. Its irregular outline, marked by a heavy black border, also recalls the wavy outline of the human brain.

The content of this "thought bubble" is itself composed of a series of intericonic references. The central human figure, partly inscribed in superimposed circles may be an allusion to the Vitruvian Man by Leonardo da Vinci, while the groups of concentric circles with the sun orbiting around the Earth refer to Renaissance geocentric representations of the universe. The yellow color of the background recalls the engraved copper plates on which these representations were chiseled. Though children 
may recognize some elements like the Earth or the sun, and a complicated process happening in the boy's head, they are unlikely to identify the references without an adult's help. This could be what McKean's complex technique and intericonic allusions are aiming at, since he illustrates stories that Gaiman imagines for a dual audience of adults and children.

Many visual motifs have been recycled throughout the book, like the Greek Sphinx on the stairs of Blinky's house. Some characters borrow features from movies, such as Blinky's butler, whose bow-tie, dark jacket and profile are reminiscent of Edgar the Butler, in Disney's The Aristocats, or from other picture books, such as the Queen of Melanesia who is wearing a ship on her head and recalls Deborah Nourse Lattimore's The Lady with a Ship on her Head.

Patti's house, where the children will finally find their father, offers the opportunity of recycling a literary and artistic motif (Figure 1). Gaiman chooses not to describe the place at all, and McKean decides to represent it as a mill. The ideational meaning conveyed by the huge mill, towering over the tiny silhouettes of the two children is reminiscent of that of the mills which Don Quixotte considered as giants. The low angle point of view, the central perspective materialized by the lines of roughly sketched houses bordering the road, and the central position of the children in rear view-which emphasizes their different heights - reveal similarities in visual composition to one of Gustave Doré's illustration for Miguel de Cervantes's book: "Plus nous avançons et plus la nuit se ferme" (The further we go, the darker the night) (Figure 2). 


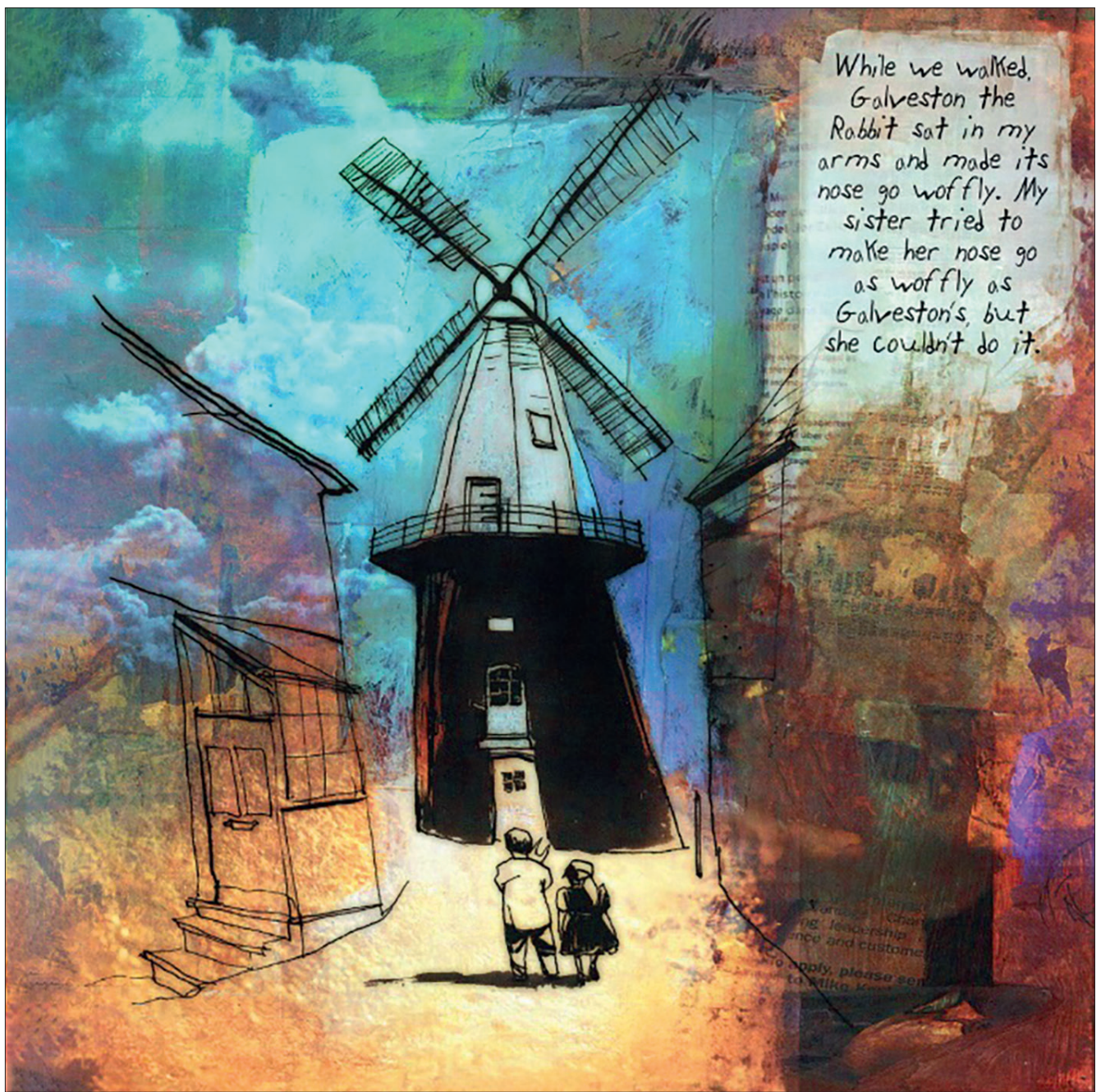

Figure 1: Dave McKean (1963- ). Illustration for The Day I swapped My Dad for Two Goldfish (2004). "While we walked, Galveston the rabbit sat in my arms." Text copyright (C) Neil Gaiman 1997. New material copyright (C) Neil Gaiman 2004. Illustrations copyright (C) Dave McKean 1997. New material copyright (C Dave McKean 2004. 


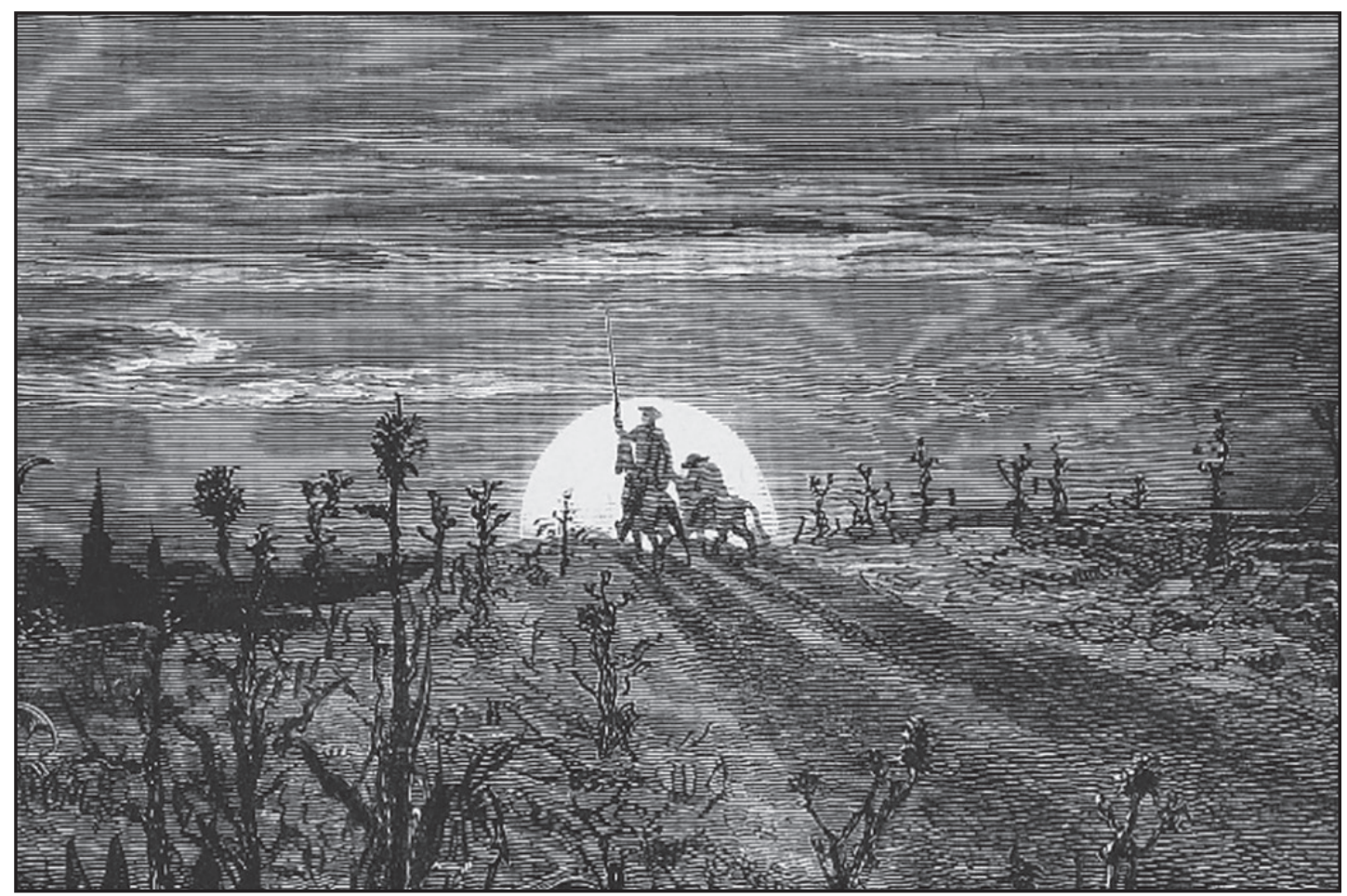

Figure 2: Gustave Doré (1832-1883). "Plus nous avançons plus la nuit se ferme" (The further we go, the darker the night) in Miguel de Cervantes, Don Quichotte (1863). Paris, BnF Gallica.

The pictorial reference to the ridiculous adventures of the famous knight-errant adds unexpected meaning to Gaiman's narrative, revealing several common elements between the two stories. Like Don Quixotte, the hero of The Day I Swapped My Dad for Two Goldfish takes an absurd decision at the beginning of the narrative, goes on a subsequent quest during which he fights, is laughed at, and when he comes back home at the end of his adventures, he is not completely cured of his nonsensical ideas. 


\section{2. Transformation of the motif of the wolf: The Wolves in the Walls}

In The Wolves in the Walls, Gaiman and McKean transform the traditional representation of the wolf. Lucy, the child heroine, hears noises in the walls of her house, which, in her opinion, are caused by hidden wolves. Her parents and her brother try to rationalize her fears, until one night, the wolves come out of the walls and the family runs out of the house to live in the garden. When Lucy tiptoes back to her bedroom to retrieve her forgotten pig-puppet, she discovers a huge wolf asleep on her bed. The presence of the wolf on Lucy's bed is obviously an intertextual allusion to the tale of Little Red Riding Hood. The pen and ink technique and the naturalistic style of depiction chosen is also reminiscent of $19^{\text {th }}$ century illustrations of the wolf, such as Doré's in Charles Perrault's "Histoire de la galette du petit Chaperon rouge" (Figures 3 and 4).

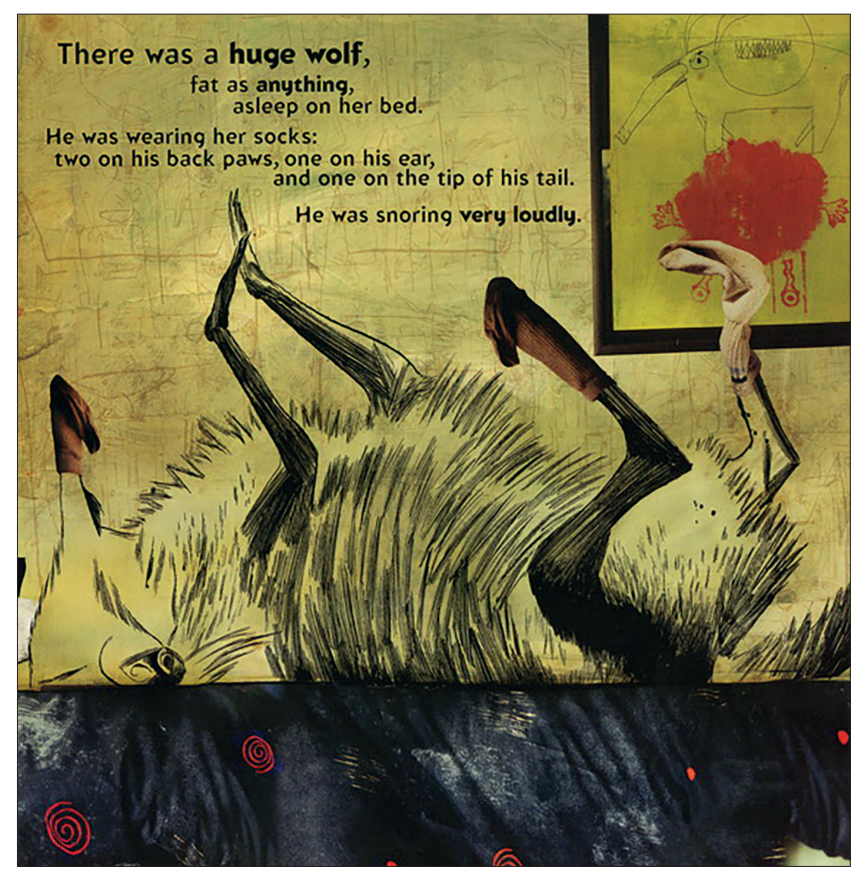

Figure 3: Dave McKean (1963- ), Illustration for The Wolves I the Walls, 2003 edition. "There was a huge wolf [...] asleep on her bed" Text copyright (C Neil Gaiman 2003. Illustrations copyright $@$ Dave McKean 2003. 


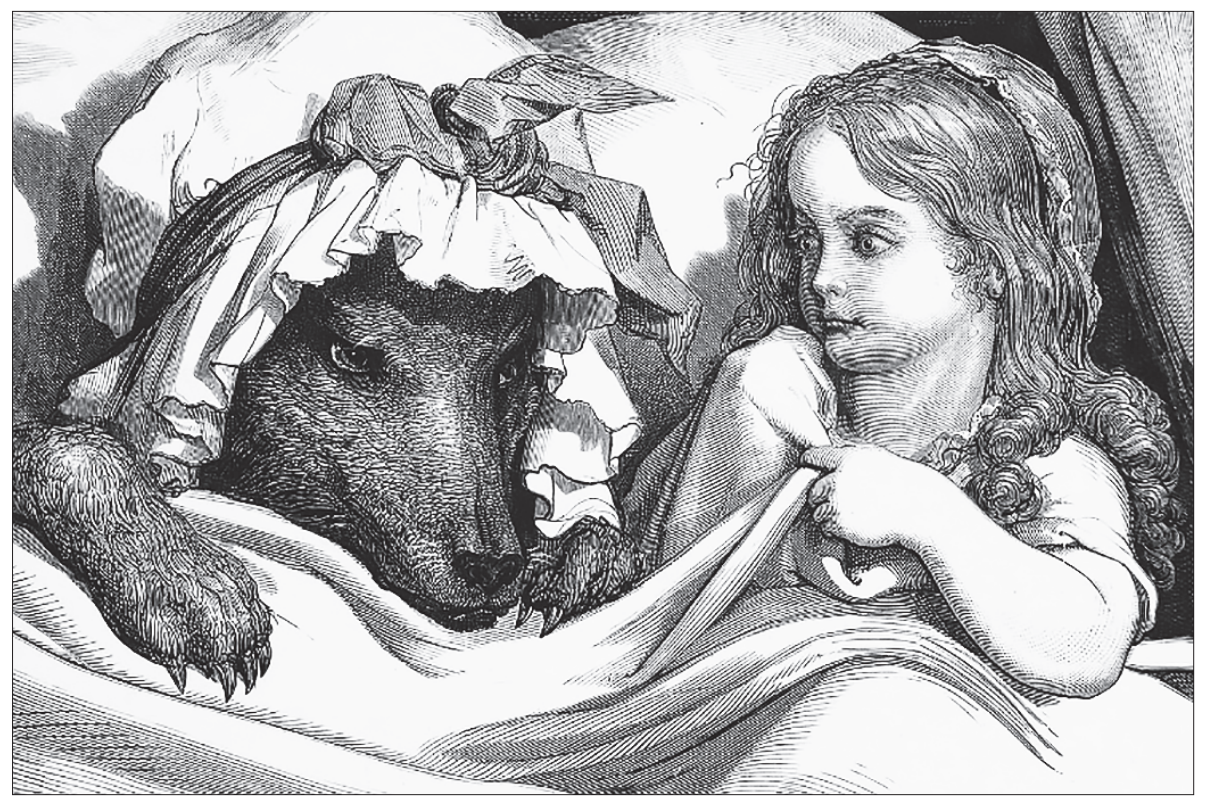

Figure 4: Gustave Doré (1832-1883). "Le Chaperon rouge fut bien étonnée de voir comment sa grand-mère était faite en son déshabillé". Illustration for Histoire de la galette et du petit Chaperon rouge by Charles Perrault.

However, while the characters represented - a little girl and a wolf - provide similar ideational meaning, the style of representation reveals quite a different intertextual content. Doré's naturalistic style produces a much more realistic representation of the wolf lying in bed next to the little girl, with a great accuracy of details in the animal's features achieved through varying of density of the tight black strokes which provide volume and a real-life effect. In contrast, McKean chooses a flatter representation with little lighting effects, which enhances the drawing process in the depiction of the character and thus, its fictional dimension. The depiction of the wolf in a grotesque human position-lying akimbo with Lucy's socks on, the curling line around its muzzle evoking a human smile - has been interpreted by Christine Wilkie-Stibbs as "the image of the replete and seducing father" (Wilkie-Stibbs 47-8). McKean's representation of the wolf, asleep, alone on the bed in a helpless attitude makes it a harmless and ridiculous character, completely different from the threatening beast with fierce eyes and sharp claws in Doré's illustration. 
Just as Gaiman plays with Freudian interpretation of dreams and the Oedipus complex, McKean's images transform the traditional motif of the wolf as a funny fictional creature which is no longer threatening, but represents the projected fantasy of the child in the $21^{\text {st }}$ century. In contrast to McKean's use of pseudomorphosis to transform traditional or mythical motifs in The Day I Swapped My Dad for Two Goldfish and The Wolves in the Walls, Shaun Tan reinterprets paintings as he introduces them in The Lost Thing.

\section{Shaun Tan: reinterpreting the meaning of things}

\section{1. Setting the world of The Lost Thing in Australian suburbia}

Tan explains that the world he develops in The Lost Thing was inspired by his father's old engineering and physics textbooks, which he cut to pieces to create a place "where this was the only illustrated literature available" (Tan, "Words and Pictures, an Intimate Distance" n.p.).

The subversion of the original meaning of recycled images is obvious from the very front cover, whose background consists of cut-outs from the scientific textbooks evoked by Tan. Above the collage of letters in individual frames which constitutes the title, there appears an image which borrows its structure, its composition and its greyish hue from Cahill Expressway, a painting by Jeffrey Smart (1962). The visual organization of Tan's image together with many of its elements - such as the curved expressway, the bridge, the cluster of buildings, the statue - constitute textual and ideational references to Smart's painting (Figures 5 and 6).

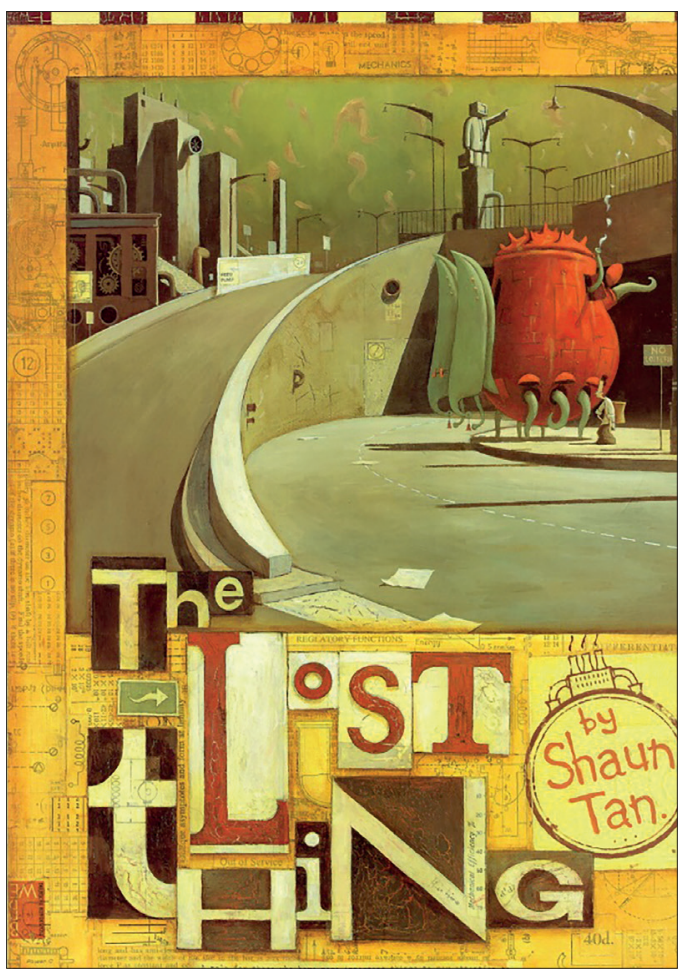

Figure 5: Shaun Tan (1973- ), front cover for The Lost Thing, 2000. Acrylic, oils and collage. (C) Shaun Tan 2000. 


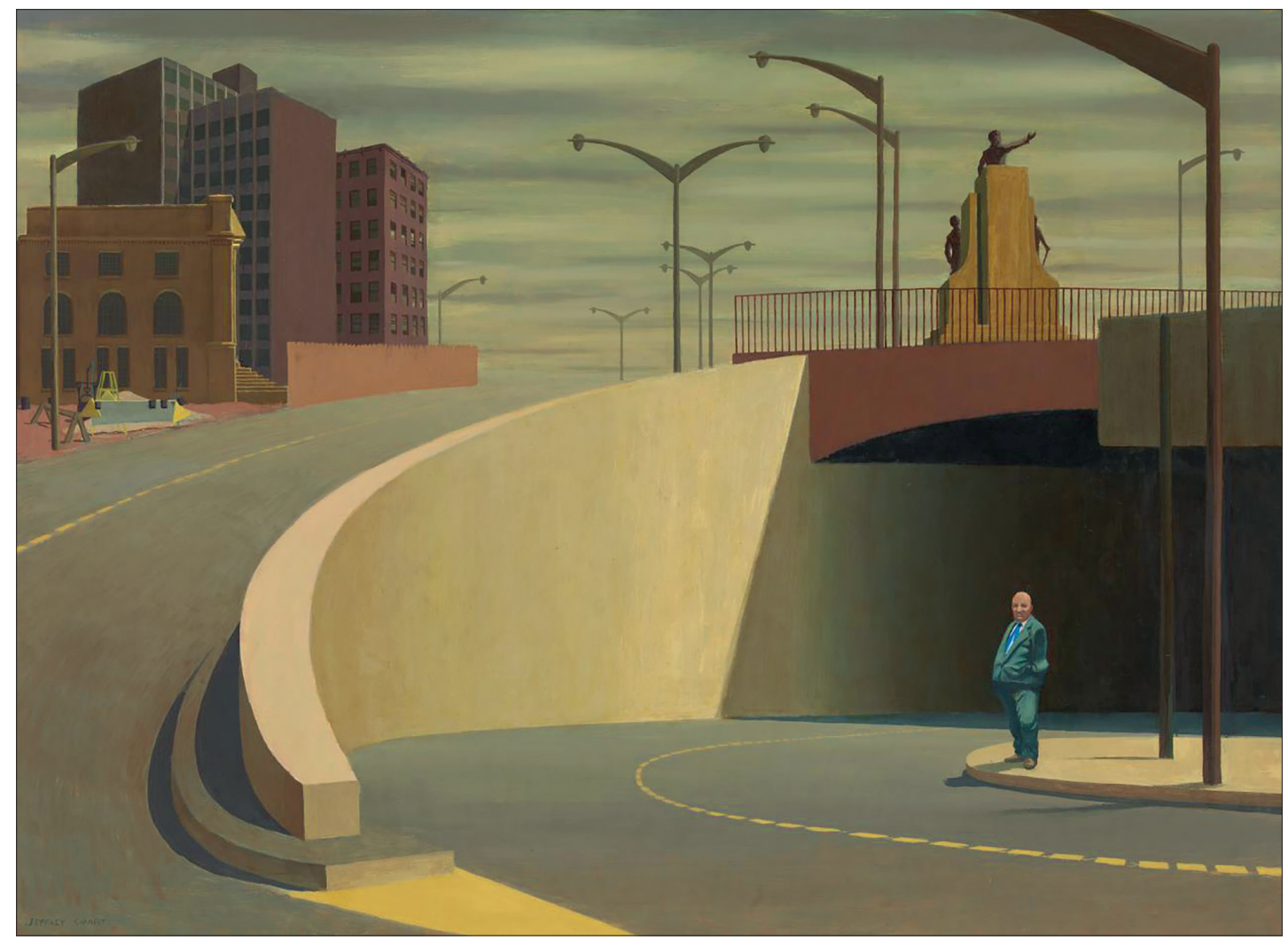

Figure 6: Smart, Jeffrey (1921-2013), Cahill Expressway. Oil on canvas (1962). 81.9 x $111.3 \mathrm{~cm}$. Melbourne: National Gallery of Victoria. (C) National Gallery of Victoria.

Tan subtly modifies Smart's Australian suburban landscape to highlight the specific features of the society he sets his story in. The pipes, cogs and wheels added to the buildings assert the dominant position of industry, signage such as "no loitering" proclaims the importance of rules, while the monitor-headed statue of a man with a briefcase - in place of Smart's war memorial-displays the power of bureaucracy. The most consequent change consists in the introduction of the Lost Thing, 
whose gigantic size, incongruous shape and saturated red in a world of grey and brown muted colors, brings new ideational and interpersonal meaning which marks it as a creature that does not belong.

\section{2. Linking The Lost Thing to contemporary society}

In The Lost Thing, recycled paintings blend silently with Tan's other images. The scene displaying the hero and the Lost Thing waiting for the tram reproduces almost exactly Early Sunday Morning, a 1930 painting by Edward Hopper. As he appropriates the original image-replacing the saturated colors by muted tones, adding wheels and pipes, and introducing his protagonists in the desert street-Tan borrows Hopper's realistic atmosphere to link his tale to contemporary society. The lettering in the store front windows, no longer illegible as in Hopper's painting, highlights the derision of the depicted society through absurd or hyperbolic expressions such as "Algebraic Equations", "Vacuum tubes for all season" or "Bob's Gasket Emporium," investing Hopper's original painting with a new meaning. The same circumstances - his protagonists waiting for the tram-provide Tan with the opportunity to reinterpret another image. This time, Tan selects a picture by the Australian artist John Brack, Collins St, 5p.m. (1955) (Figures 7 and 8).

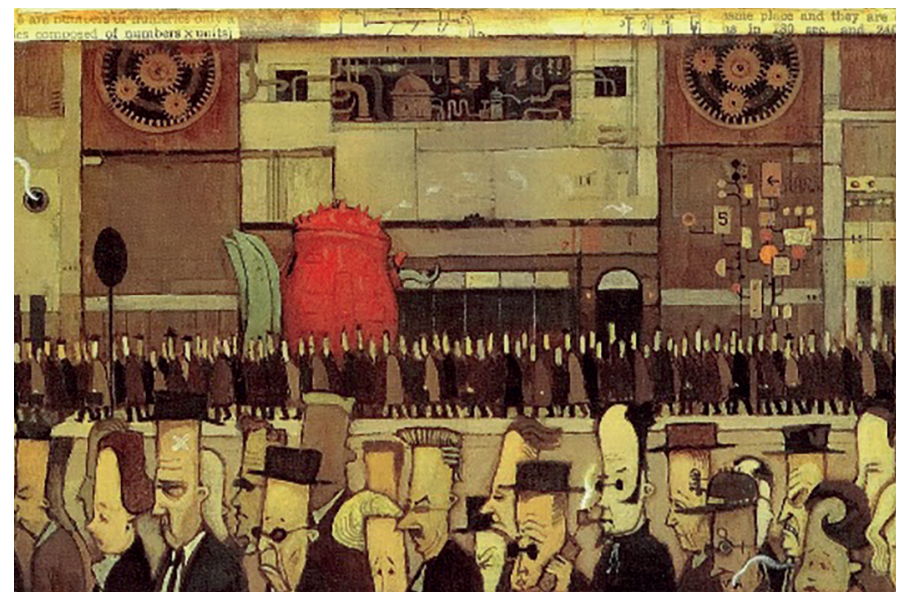

Figure 7: Shaun Tan (1973- ), illustration for The Lost Thing, 2000. "The next morning we caught a tram into the city". Acrylic, oils and collage. (C) Shaun Tan 2000. Permission to use the image by Hachette Australia. 


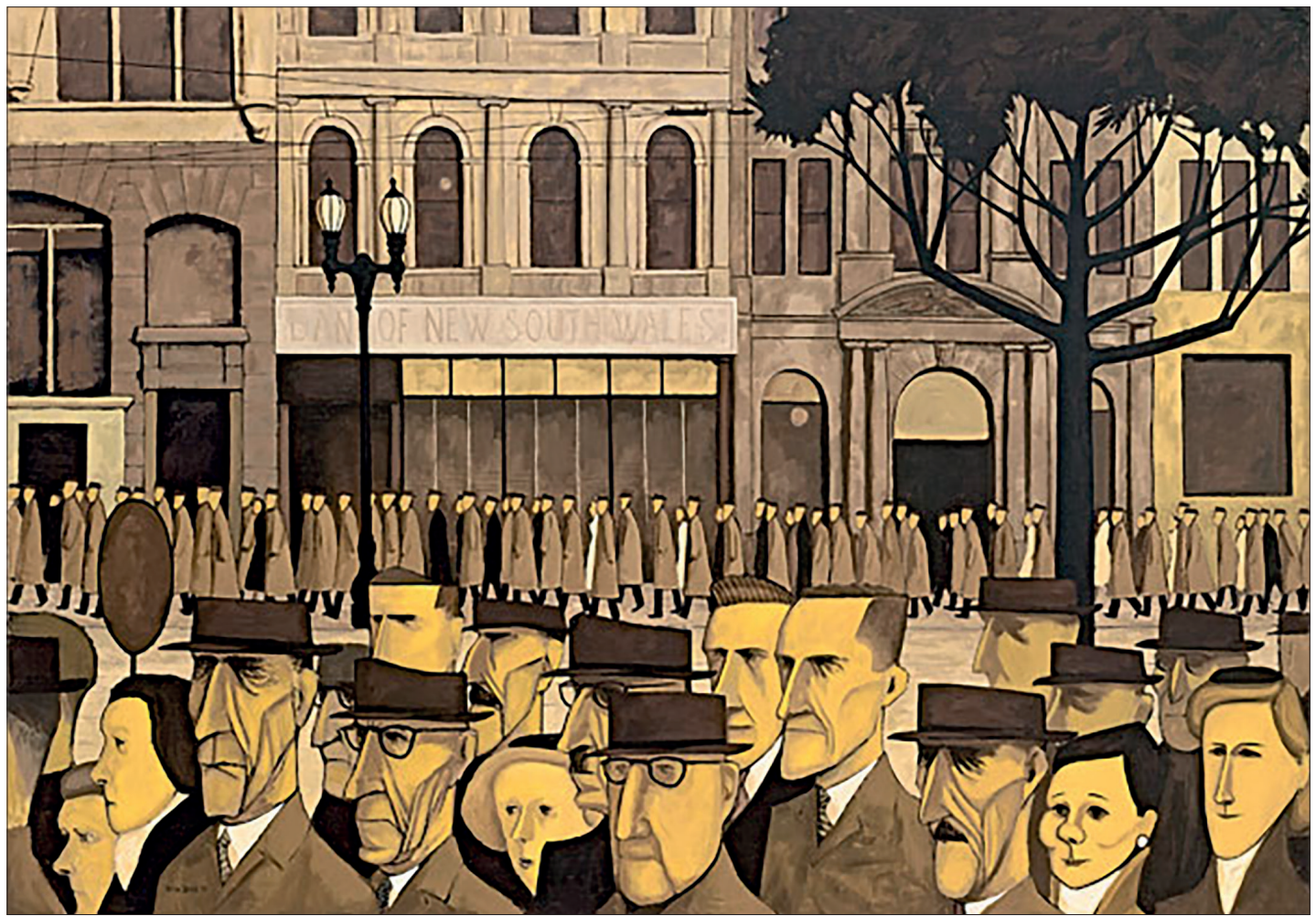

Figure 8: John Brack (1920-1999), Collins St, 5p.m. Oil on canvas (1955). 114.8 x $162.8 \mathrm{~cm}$. Melbourne: National Gallery of Victoria. (C) National Gallery of Victoria. Permission to use the image for study by NGV.

Again, Tan borrows the visual organization and the main focus groups from the original painting. Brack's grid-like structure-determined by the streams of walking people and intermittent vertical elements in the background-imparts the scene with a sense of order enhancing the power of machines, whose cogs and wheels are visible in two round openings which look like two eyes watching over the crowd. The amplification of Brack's long faces and tall foreheads generates an alienating effect that highlights the dysfunctioning of the depicted society in which the bright odd shape of the Lost Thing stands out as a creative joke. 
Tan's reinterpretation of Brack's painting is operated through textual meaning developed by the collage of textual snippets borrowed from physics and engineering textbooks in the margin. "FORCE ON CURRENT," on the right-hand side, is used in physics for a magnetic force on a current carrying wire. In Tan's collage, it seems to describe the stream of faceless people walking in the background, which can be compared to an electric current in which the idea of individuality is not relevant. "HARMONICAL PROGRESSION," on the left hand-side in the image, refers to a mathematical progression, in which every element can be calculated from the preceding one. It reads like the author's ironical comment upon the stream of characters in the foreground, all of which look different but similarly unsatisfied and unable to communicate. Tan thus transforms and reinterprets Brack's painting to link the dystopian world of The Lost Thing to Australian society and expose its dysfunctioning.

\section{4. Acknowledging his sources}

Tan mentions his sources in the same subtly joking manner he uses throughout The Lost Thing. The last page of the book turns out to be a thank you page — revealed by the expression "with THANKS" stuck in the margin, under the image. By turning the book, it is then possible to find in the same margin the names of all the persons and institutions that Tan thanks, and, upside down, a series of four collages which reads: "And APOLOGIES to Jeffrey Smart, Edward Hopper \& John Brack." Though he does not cite the images he recycled, an adult reader may find them without difficulty on the Internet, as they are among the most famous paintings by these artists. The disguise of "apologies" is thus a way to invite readers to research the following names and discover the original paintings. To find out this underlying meaning, a child reader/viewer needs an adult to reveal the cultural and social dimension of the recycled image. In addition to the ideational meaning carried by the elements represented in it, and to the textual meaning conveyed by the visual composition, the recycled image thus develops interpersonal meaning as it links the child viewer, the adult reader, the artist and the painter whose work inspired the picture book image.

\section{Conclusion}

Panofsky's two methods to describe intericonic interpretation have proved adequate to analyze the recycling of images in the three picture books retained in this paper. Through pseudomorphosis, McKean recycles multiple motifs from famous works of art or from former picture books to parallel the playful recycling of themes or characters from tales in Gaiman's writing, such as Don Quixotte's 
absurd quest, in The Day I Swapped My Dad for Two Goldfish or the wolf in The Wolves in the Walls, which his flat pen and ink depiction transforms into a grotesque but harmless animal.

By contrast, Tan favors reinterpretation processes as he recycles paintings of urban landscapes by realist Australian and American artists such as Jeffrey Smart, Edward Hopper and John Brack in the images of The Lost Thing. Preserving the visual composition and the main focus groups of the original paintings, he introduces subtle ironical comments linking his nightmarish world — in which plumbing, machines and bureaucracy seem to replace direct communication between people - to contemporary western society. Reinterpretation thus becomes a means to question the society his readers live in.

In the picture books examined above, the recycling of visual elements, motifs or settings from previous works of art adds cultural and social meaning to the image they are introduced in. In a way comparable to messages in a palimpsest, the recycled elements, integrated in the new context of the picture book require an expert eye to reveal their specific meaning. Thus, they enrich the pedagogical dimension of the picture book as they invite the adult reader to explain the hidden references to the child not yet culturally trained to identify them. As many picture books illustrators recycle works of art or motifs in their images - such as Anthony Browne in Changes, David Wiesner in The Three Pigs or Ian Falconer in Olivia - the systemic functional approach to visual meaning (Painter, Martin, and Unsworth) associated to Panofsky's processes of pseudomorphosis and reinterpretation may prove useful to understand the connoted message of the image.

\section{Works Cited}

ARRIVÉ, Mathilde. “L’intelligence Des Images. L'intericonicité, Enjeux et Méthodes.” E-rea 13.1 (2015): 1-22. URL: https://journals.openedition.org/erea/4620 (page accessed May 14, 2019).

BARTHES, Roland. "Rhétorique de l'image.” Communications 4 (1964): 40-51.

BENJAMIN, Walter. "The Work of Art in the Age of Mechanical Reproduction." Illuminations. Ed. Hannah Arendt. Transl. from German by Harry Zohn. New York: Schocken Books, 1969. URL: http://web.mit. edu/allanmc/www/benjamin.pdf (page accessed May 14, 2019).

BEYLOT, Pierre (ed.). Emprunts et citations dans le champ artistique. Paris: L'Harmattan, 2004.

CHÉROUX, Clément. “Le Déjà-vu du 11 Septembre. Essai d'intericonicité.” Études photographiques (2007): 148-173. URL: https://journals.openedition.org/etudesphotographiques/998 (page accessed May, 13 2019).

DOUGLAS, Virginie. "Dave McKean.” Images des livres pour la jeunesse. Eds. Annick Lorant-Jolly and Sophie Van der Linden. Paris: Éditions Thierry Magnier / CRDP académie de Créteil, 2006. 140-145. 
EDELINE, Francis, KLINKENBERG Jean-Marie and Philippe MINGUET. Groupe $\mu$ : Traité du signe visuel. Pour une rhétorique de l'image. Paris: Éditions du Seuil, 1992.

GAIMAN, Neil and Dave McKEAN. The Day I Swapped My Dad for Two Goldfish. Clarkston: White Wolf Publishing, 1997.

—. The Day I Swapped My Dad for Two Goldfish. New York: HarperCollins, 2004

—. The Wolves in the Walls. New York: HarperCollins Children's Books, 2003.

GAIMAN, Neil and Celia RICHARD. "Interview by Celia Richard.” 2015. URL: http://www.scottishbooktrust. com/podcasts/audio/neil-gaiman-interview-the-graveyard-book (page accessed May, 14 2019).

GENETTE, Gérard. Palimpsestes. La Littérature Au Second Degré. Paris: Le Seuil, 1982.

HARIMAN, Robert and John L. LUCAITES. No Caption Needed: Iconic Photographs, Public Culture and Liberal Democracy. Chicago: Chicago University Press, 2007

KRESS, Gunther and Theo VAN LEEUWEN. Reading Images: The Grammar of Visual Design. New York: Routledge, 2006.

KRISTEVA, Julia. Semiotikè. Recherches pour une sémanalyse. Paris: Éditions du Seuil, 1969.

LATOUR, Bruno. Sur le Culte moderne des dieux faitiches suivi de Iconoclash. Paris: La Découverte, 2009.

PAINTER, Clare, MARTIN James Robert and Len UNSWORTH. Reading Visual Narratives: Image Analysis of Children's Picture Books. Sheffield: Equinox Publishing, 2013.

PANOFSKY, Erwin. "Renaissance and Renascences in Western Art." The Kenyon Review 6.2 (1944): 201-236. URL: https://www.jstor.org/stable/4332493 (page accessed May, 14 2019).

—. Studies in Iconology. Oxford: Oxford University Press, 1939.

SALISBURY, Martin and Morag STYLES. Children's Picturebooks: The Art of Visual Storytelling. London: Laurence King Publishing, 2012.

TAN, Shaun. “Picture Books: Who Are They For?” URL: http://www.shauntan.net/essay1.html (page accessed May, 14 2019).

—. The Lost Thing. Sydney: Hachette Australia, 2000.

—. "Words and Pictures: An Intimate Distance." URL: http://www.shauntan.net/comments1.html (page accessed May, 14 2019).

WILKIE-STIBBS, Christine. "Imaging Fear: Inside the Worlds of Neil Gaiman (a Reading)." The Lion and the Unicorn 37.1 (2013): 1-7. 
Abstract: Kress and van Leeuwen showed that the visual could be considered as a semiotic mode, and developed a systemic-functional model of visual meaning. Drawing on Painter's, Martin's and Unsworth's adaptation of their model to picture books, and on Panofsky' approach to iconology, this paper contends that recycled images conceal different levels of meaning and function as palimpsests. The first part presents different approaches to visual meaning, and the shift in the function of the work of art, as pointed out by Benjamin. The following parts analyze the type of visual meaning developed by recycled images in two picture books written by Neil Gaiman and illustrated by Dave McKean, and one by Shaun Tan. The article suggests that the processes identified by Panofsky in his analysis of meaning in works of art can be successfully associated to a systemic-functional model of visual meaning to reveal the function of recycled images in contemporary picture books.

Résumé : Kress et van Leeuwen ont établi le fait que l'image peut être considérée comme un mode sémiotique et ont développé un modèle d'analyse du sens porté par l'image, basé sur une approche systémique fonctionnelle. S'appuyant sur l'adaptation de ce modèle aux albums pour enfants que proposent Painter, Martin et Unsworth et sur le concept d'iconologie développé par Panofsky, cet article se propose de montrer que les images recyclées dissimulent différents niveaux de sens et fonctionnent comme des palimpsestes. La première partie introduit différentes approches du sens dans l'image et le déplacement de la fonction de l'œuvre d'art, remarqué par Benjamin. Les parties suivantes analysent le type de contenu visuel développé par les images recyclées dans des albums cosignés par Neil Gaiman et Dave McKean et dans un album écrit et illustré par Shaun Tan. L'article suggère que les procédés identifiés par Panofsky dans son analyse du sens des œuvres d'art peuvent être associés à un modèle systémique fonctionnel du sens visuel pour mettre en évidence la fonction de l'image recyclée dans les albums contemporains 